\begin{tabular}{l}
\hline POLITEIA \\
Politeia: Jurnal Ilmu Politik, 11 (1) (2019): 30-48 \\
ISSN 0216-9290 (Print), ISSN 2549-175X (Online) \\
Available online https://jurnal.usu.ac.id/index.php/politeia \\
\hline
\end{tabular}

\title{
Mount Sinabung Eruption Collaboration Model in a Disaster Political Perspective
}

\author{
Ian Pasaribu1)* \& Fernanda Putra Adela ${ }^{2)}$ \\ 1)Master of Political Science Program at Diponegoro University \\ 2) Political Science Study Program, Faculty of Social and Political Sciences University of \\ Sumatera Utara, Indonesia
}

Accepted December 2018, Approved December 2018, Published January 2019

\begin{abstract}
Abstrak
Penelitian ini, menjelaskan dan menganalisa model kerjasama penanggulangan erupsi gunung sinabung dalam perspektif politik bencana. Terletak di Kabupaten Karo, Provinsi Sumatera Utara dalam 6 tahun terakhir dari tahun 2010-2016 secara teratur mengalami erupsi. Masih ada masalah penanggulangan mengingat masih ada kendala yang dihadapi oleh (stakeholders). Perumusan penelitian ini adalah bagaimana kerjasama dan koordinasi pemangku kepentingan dalam penanggulangan erupsi Gunung Sinabung. Apa kebijakan kendala bencana di Sumatera Utara yang belum berhasil menyelesaikan erupsi Gunung Sinabung. Kerangka teori dari penelitian ini menggunakan konsep kerjasama, good governance dalam manajemen bencana, koordinasi dan manajemen bencana konsep kemudian untuk menganalisis peneliti telah memetakan peran pemangku kepentingan yang berbeda seperti pemerintah pusat, pemerintah daerah, pengusaha, LSM dan masyarakat. Penelitian ini merupakan penelitian kualitatif dengan paradigma kritis untuk menjelaskan fenomena dan menemukan model baru dengan menempatkan sebuah wawancara sebagai data primer dan buku-buku, jurnal internasional dan jurnal nasional. Hasil dari penelitian ini menunjukkan bahwa model kerjasama Penangulangan erupsi gunung sinabung adalah mengkoordinasikan stakeholders Gunung Sinabung, manajemen bencana letusan, kendala kebijakan manajemen bencana di Sumatera Utara yang belum berhasil menyelesaikan letusan Sinabung, manajemen bencana rekomendasi kebijakan letusan Gunung Sinabung. Pada akhir hasil penelitian ini menunjukkan skema model kerjasama penanggulangan bencana dan juga menjelaskan pentingnya Sinabung menjadi bencana nasional.
\end{abstract}

Kata Kunci: Kerjasama, Manajemen Bencana dan Politik Bencana

\section{Abstract}

This research, explained and analyzed the collaboration model of eruption of Mount Sinabung eruption in a disaster political perspective. Located in Karo District, North Sumatra Province in the last 6 years from 2010-2016 regularly experienced eruptions. There are still countermeasures problems considering there are still obstacles faced by (stakeholders). The formulation of this research is how the cooperation and coordination of stakeholders in the eruption prevention of Mount Sinabung. What is the policy of disaster disasters in North Sumatra that has not succeeded in completing the eruption of Mount Sinabung. The theoretical framework of this study using the concept of cooperation, good governance in disaster management, coordination and disaster management concepts then to analyze researchers has mapped the role of different stakeholders such as the central government, local government, employers, NGOs and the community. This research is a qualitative research with a critical paradigm to explain phenomena and find new models by placing an interview as primary data and books, international journals and national journals. The results of this study indicate that the collaborative model of Sinabung eruption cooperation is coordinating Mount Sinabung stakeholders, eruption disaster management, disaster management policy constraints in North Sumatra that have not succeeded in completing the Sinabung eruption, disaster management policy recommendations for the Mount Sinabung eruption. At the end of the results of this study, the scheme of the model for collaborative disaster management and also explaining the importance of Sinabung became a national disaster.

Keywords: Cooperation, Disaster Management and Disaster Politics

How to cite: Pasaribu, I. (2018), Model Kerjasama Penanggulangan Erupsi Gunung Sinabung dalam perspektif Politik Bencana, Politeia: Jurnal Ilmu Politik, Vol 11, (1): 30-48

*Corresponding author:

E-mail: Ianpasaribu20@gmail.com 
Ian Pasaribu \& Fernanda Putra Adela, Mount Sinabung Eruption Collaboration Model in a

\section{INTRODUCTION}

The benchmark for regional success has been to overcome difficulties in tackling disasters, namely areas prior to disasters, disaster response and postdisaster. This success has never been separated from the patterns of cooperation carried out by various parties that involve the interests involved in it. More than that, it is common to happen from time to time.

Mount Sinabung is one of the active Mount Merapi located in Karo District, North Sumatra Province. Since 2010 to 2015 Mount Sinabung has regularly erupted. It has been recorded since 2010 that Mount Sinabung has had four eruptions, 2010, 2013, 2014 and 2015. The Sinabung eruption response has not been maximized considering there are still obstacles faced by the central government, regional government, North Sumatra BPBD, NGOs, entrepreneurs, especially the surrounding the Sinabung region which has been a major victim in recent years.

There are two main reasons why this collaborative research on the eruption management of Mount Sinabung is important that is the empirical and theoretical background. The empirical background is based on the following considerations:

In experience, the area adjacent to the volcano is indeed fertile, suitable for farming and settlement. The volcano area was initially covered by dense forests so that there were many water sources. Most of this water source is used as a source of municipal drinking water or is a source of river water flowing around the surrounding area, supporting the lower agricultural area. The number of disasters that occur and cause casualties and property losses, has opened our eyes together that disaster management in our country is still very far from what we have expected.

So far, disaster management is considered not a priority and only comes at any time, even though we live in an area prone to the threat of disaster. Therefore an understanding of disaster management needs to be understood and mastered by all circles, both government, society, and the private sector. Activities in the predisaster phase have been forgotten so far, even though the activities in the pre-disaster stage are very important because what has been prepared at this stage is capital in facing disasters and post-disaster. Very slight governments with the public and private sector think about what steps or activities need to be done in dealing with disasters or how to minimize the impact of disasters. (Soehatman Ramli, 2011: 65-66)

As a result of the rapid growth of the population in Indonesia, part of the forest on the slopes of the volcano began to be encroached and converted into plantation or agricultural areas. Residents began to settle and villages formed on the slopes of volcanoes, which were actually areas prone to volcanic hazards that could come at any time. People who live on the slopes of volcanoes, which are actually disasterprone areas, come with their own desires, farming, forming groups of villages and villages. 
The main threat to the impact of the Volcano is the hot clouds that come out of the crater of the mountain. Hot clouds whose residential areas are located on the slopes can be threatened. Then volcanic ash and rain lava which can cause cold lava floods that can sweep the area (Sukandarrumidi, 2010: 177).

The number of volcanoes in Indonesia, both active and inactive, is approximately 400 mountains. From these, 70 of them are still active. Volcanoes in Indonesia are grouped into five: the Sunda volcano, the Banda volcano, the Minahasa and Sangihe volcanoes, the Halmahera volcano, the Sulawesi volcano and Bonthain volcano.

North Sumatra is the fourth largest province in Indonesia after West Java, East Java and Central Java. According to the 2010 population census, the population in North Sumatra Province is $12,985,075$ people In North Sumatra along with Mount Sibayak, Mount Sinabung are two active mountains with peaks reaching 2,451 meters. Mount Sinabung has not erupted since 1600 but has suddenly been active again by erupting in 2010 until now (BPS North Sumatra Province, 2010).

On August 27th, 2010 Mount Sinabung emitted volcanic smoke and ash. On August 29th, 2010 at around 00.15 WIB Mount Sinabung spews lava. Mountain status is raised to be alert. Twelve thousand residents were evacuated and accommodated in 8 locations, one person was declared dead at the event. In the same year, September Mount Sinabung erupted two eruptions, first on September 3 and September 7. In 2013, Mount Sinabung erupted again until 18 September 2013 there were 4 eruptions. As a result of the eruption, Mount Sinabung was raised to level 3 standby. Entering November, there was an increase in activity with increasingly strong eruptions till on 3 November 2013 at 03.00 the status was raised again to become Alert. The displacement of residents in villages around a distance of $5 \mathrm{~km}$ was carried out.

Eruptions occurred many times after that, accompanied by glides of hot clouds up to $1.5 \mathrm{~km}$. On November $20^{\text {th }}, 2013$ there were six eruptions since early morning. Eruptions (eruptions) occurred again four times on November 23rd, 2013 since the afternoon, continued the following day, five times.

An $8000 \mathrm{~m}$ high ash column is formed on top of the mountain. As a result of this series of eruptions, the city of Medan which is $80 \mathrm{~km}$ to the east is exposed to rain of volcanic ash. Level 4 status (alert) continues to last until entering 2014. Drops of incandescent lava and hot cloud bursts continue to occur until January 3, 2014.

Starting on January $4^{\text {th }}, 2014$ a series of earthquakes, eruptions and hot clouds continued until the following day. This forced additional residents to evacuate, to more than 20 thousand people. After this condition persisted, in the last week of January 2014 the condition of Mount Sinabung began to stabilize and it was planned that refugees from outside the danger radius $(5 \mathrm{~km})$ could be returned. However, a day later 14 people were 
Ian Pasaribu \& Fernanda Putra Adela, Mount Sinabung Eruption Collaboration Model in a

found dead and 3 people were injured by a hot cloud glide while they were visiting Suka Meriah Village, Payung District. While on August 5th, 2015 at 11:11 a.m., there was a 2,500-meter heat cloud going to the southeast-east sector with a 1,500-meter volcanic ash column. The hot cloud of avalanches occurred at 17.33 WIB which slid 3,000 meters to the southeast-east with a height of 2,000 meters of volcanic ash. The condition, he said, caused 3,152 households or 11,114 people to remain in 10 refugee camps. In addition, 2,053 households $(6,179$ people) still have to settle in temporary shelters while waiting for relocation (North Sumatra BPBD 2014).

One of the government's efforts is to make refugee posts and replace refugees. Overcoming difficulties to help the victims, but in reality there are still irregularities. More than just government assistance. Mount Sinabung, aside from leaving trauma and panic, also left several problems in the fields of health, education and the economy. Hundreds of residents succeeded in Kabanjahe Hospital (Karo District), because they suffered from Acute Respiratory Infection (ARI) due to the eruption. Volcanic disaster management based on existing systems is improved from the previous to completion. (Hartini Retnaningsih, 2013: 10).

Various policies to reduce the risk of an eruption of Mount Sinabung in mitigation, preparedness, emergency response and recovery efforts have been accommodated. However, it was found that there were still various obstacles both in the government and in the community during the emergency response phase and the eruption of Mount Sinabung. This condition is certainly different from the disaster management model taken in many countries that have a systematic approach from pre-disaster (Lestari et al., 2010).

In the fourth paragraph of the Preamble of the 1945 Constitution clearly states that "the Republic of Indonesia is responsible for protecting the whole people of Indonesia and the entire homeland of Indonesia." Thus the Indonesian Government is obliged to provide protection for life and livelihoods including protection from disaster threats in order to realize the general welfare translated into the articles.

Various laws and regulations have been established in an effort to provide protection to the people from disasters such as Law Number 6 of 1974 concerning the Principles of Social Welfare. Law Number 20 of 1982 concerning General Provisions for State Defense and Security. Law No. 4 of 1984 concerning Infectious Diseases. Law Number 32 of 1992 concerning Health. Law Number 24 of 1992 concerning Spatial Planning. Law Number 41 of 1999 concerning Forestry. Law Number 22 of 2001 concerning Oil and Gas. Law Number 3 of 2002 concerning National Defense. Law Number 32 of 2004 concerning Regional Government. Law Number 7 of 2004 concerning Water Resources.

Law Number 24 of 2007 concerning Disaster Management. In accordance with the mandate of the 
agreement at the national and regional level, disaster risk reduction must be one of the national development priorities. The Regional Government of North Sumatra Province should commit to immediately implement the agreement by incorporating disaster risk reduction efforts into the regional development framework. To better deal with the increasing potential and complexity of disasters in the future, Indonesia needs a plan that is integrated, coordinated and comprehensive.

The Republic of Indonesia Law Number 24 of 2007 has changed the paradigm of disaster management in Indonesia from being reactive to being proactive, namely disaster management has begun since potential disasters have not been identified in an area. The Government Regulation of the Republic of Indonesia Number 21 of 2008 further regulates the obligation to prepare disaster management planning by the Provincial Government. In this case, North Sumatra Province has made a Disaster Management Plan (RPB). Then in 2015, the Karo District Government issued a Regional Regulation Number: 362/325 / BPBD / 2015 concerning the Determination of the Extension of the Status of Upper Emergency Response to the Mount Sinabung Eruption Disaster in Karo District in 2015.

Disaster is a serious disruption to the usefulness of a society, causing widespread harm to human life in terms of material, economic or environmental and which exceeds the ability of the community concerned to overcome by using their own resources. Disasters then pose a threat that has the potential to cause damage, loss of human life, damage to the environment, and the impact of a condition determined by psychology.

A vulnerability is a condition that is determined by physical, social, economic and social-cultural and environmental factors or processes. Disasters are a consequence of a combination of natural activities (a physical event, such as a volcanic eruption, earthquake, landslide) and human activities. Losses incurred in the financial and structural fields, even to death caused by human helplessness due to poor management of emergencies (UNISDR Terminology on Disaster Risk Reduction 2009).

Activities during disasters that are carried out immediately at the time of a disaster, to overcome the impacts, especially in the form of saving victims and property, evacuation and evacuation, will get full attention from both the government and the private sector and the community. At the time of the disaster, there are usually so many parties who pay attention and lend a hand to provide energy, morale and material assistance.

The amount of assistance that comes is actually an advantage that must be managed properly, so that any assistance that enters can be effective, right on target, right for benefits, and efficiency occurs. The level of public and local government awareness and understanding is very important at this stage to be able to determine the steps needed to reduce the impact of the disaster.

In addition, other types of preparation are spatial planning that 
Ian Pasaribu \& Fernanda Putra Adela, Mount Sinabung Eruption Collaboration Model in a

places the location of public facilities and social facilities outside the disaster hazard zone (non-structural mitigation), as well as engineering efforts to build a structure that is safe from disasters and protects the structure of disasters (mitigation structures). Meanwhile, efforts to strengthen local government in pre / pre-disaster activities can be done through strengthening existing units / institutions and training their apparatuses as well as coordinating with institutions between regions and at the national level, given that disasters do not recognize administrative areas, so that each region has potential disaster management plans in the region. (Study of Disaster Mapping in North Sumatra Province, Research and Development Agency of North Sumatra Province 2011).

This formulation process is expected to continue to develop so that a guideline for threat and vulnerability assessment and a standard disaster risk assessment will be obtained. The next activity can be carried out through technical consultations, both from the private sector and academics, as has been done in many other countries. Stakeholders including regional government associations, nongovernmental organizations (NGOs), entrepreneurs and the private sector, the media and the wider public were involved in providing input in the preparation of the National Disaster Management Plan. The implementation was carried out through planning workshops, public consultations, and input through various public media.
According to those reasons this research departs from empirical and theoretical backgrounds. Strengthening the role of stakeholders, entrepreneurs and the community is important in terms of forming a solid collaboration forum. The disaster of Mount Sinabung eruption is certainly a problem for the survival of residents around Mount Sinabung so that a disaster management effort is needed that is able to answer the problem of sinabung eruption, besides that it also requires a management collaboration between vendors, entrepreneurs and communities in disaster management.

\section{RESEARCH METHODOLOGY}

This study uses a qualitative method. Where researchers collect data from in-depth interviews with various speakers who have capacity and capability related to disasters, environmental politics, government, NGOs and the community. In determining the resource person, the researcher used a Purposive Sampling technique in which the researcher directly determined the resource person in accordance with the capacity and competence related to this research. The researcher interviewed the USU FISIP Professor $\mathrm{Mr}$ Prof. Hamdani said, Interview with the Secretary of the BPBD Karo Regency Johnson Tarigan, Interview with the District Head of Simpang Empat District Drs. Eddy Rikwan Ginting MM, Interview with North Sumatra Alfamart Public Relations Eris Estrada Sembiring, and Chair of the North Sumatra Environment Forum for Dance and 
Community Funds. The researcher also collected various other forms of qualitative data such as documents that are useful for developing a deeper understanding of this research.

\section{CONCLUSION}

\section{Stakeholder Coordination of disaster relief for the eruption of Mount Sinabung.}

Against this background, the Indonesian people should be strong in facing any danger. People need to be aware of vulnerabilities around them. The vulnerability is condition that is currently in effect or the nature/behaviour of humans or the community. However, the capacity of several elements needs to be increased to reduce the vulnerability that exists in the community. Capacity is the ability of resources to deal with threats or hazards. The characteristics of people who have resilience include that the community has the ability to anticipate, protect by avoiding and deflecting, adapting, and recovering. The thoughts underlying the strategy towards resilience include: Keep the community out of danger, Keep danger from the community, Living harmony with risk, and Grow local wisdom.

On the Mount Sinabung disaster management discourse in Karo Regency, North Sumatra was inseparable from the system that had been built before. The national disaster management system in Indonesia has improved a lot of developments to date. Meanwhile, disaster management policies are contained in Law Number 24 of 2007 concerning Disaster Management. (Interview with Hamdani Harahap on August $8^{\text {th }}, 2016$ )
And ensure that all programs and activities carried out are in line with the direction of development policy in the 2015-2019 RPJMN document. The eruption of Mount Sinabung is not part of the national disaster for which the response is in the North Sumatra regional government in collaboration with the local government of Karo district. (Interview with Secretary of the Karo District BPBD Johnson Tarigan on 2 July 2016)

If it shows an increasing trend and the potential danger threat of Mount Sinabung, a Letter from the Head of the Geology Agency will be issued which contains the results of observations and also recommendations for areas that must be immediately evacuated. The letter from the head of the BPBD was the basis for the Karo District Regent to issue a Regent Decree regarding the determination and extension of emergency response status. When the emergency response status of the position of the Regional Disaster Management Agency (BPBD) of Karo Regency became the first line to coordinate the relevant parties in the ranks of the Regional Government of Karo for the preparation of the evacuation of the disaster victims.

Entrepreneurs are an integral part of disaster management in a region anywhere in the world including Indonesia. With the limited ability of the North Sumatra government to cope with natural disasters is an event where many actors can then play a role. For companies, a disaster situation is a condition where corporate social responsibility (CSR) can be demonstrated. 
Ian Pasaribu \& Fernanda Putra Adela, Mount Sinabung Eruption Collaboration Model in a

The contribution of employers in disaster issues in the Mount Sinabung Eruption case really depends on how much the level of awareness, especially the top management, the owner or shareholder of the company. The higher the level of awareness, of course, the hope of giving a greater commitment to disaster management efforts can be realized easily. Conversely, if the level of awareness of management, owners and shareholders of the company is still low, it will be difficult to ask for more commitment to disaster management efforts. Even though with a high level of commitment, it is expected that the real contribution given by the company will be even higher. Both contributions are in the form of financial contributions (cash donations), assistance in the form of goods and or services (in-kind contributions), assistance in the form of certain free skills and assistance in other forms.

Entrepreneurs have an extractive role in making contributions in the form of CSR and companies are usually willing to provide proportional amounts of grants. Other companies like that should feel an ethical responsibility to remind that the benefits come from one specific place and that the place is currently experiencing the Mount Sinabung Eruption (interview with Alfamart Medan Public Relations, Eris Strada Sembiring August 8 th, 2016)

Entrepreneurs have an extractive role in making contributions in the form of CSR and companies are usually willing to provide proportional amounts of grants. Other companies like that should feel an ethical responsibility to remind that the benefits come from one specific place and currently the place is undergoing the Mount Sinabung Eruption (interview with Alfamart Medan Public Relations, Eris Strada Sembiring August $8^{\text {th }}, 2016$ )

Improvements strategies and the ways in which entrepreneurs contribute to disaster management in Mount Sinabung Eruption need to be continuously carried out, starting from raising awareness, strengthening commitment and increasing tangible contributions to support face preparation and disaster management. Of course, the role of all parties is needed to instil awareness in the company, especially for top management, shareholders and owners, that contributing to disaster management in Indonesia is not a burden, but as part of a strategic social investment. (Interview with Director of Walhi North Sumatra Dana Tarigan August 9th , 2016).

Considering that Karo district is a region that has a high risk of Eruption of Mount Sinabung disaster because it is located in a disaster-prone area. This condition can be "utilized" by the company to carry out the process of fostering stakeholder relations through a variety of strategic initiatives related to disaster management, such as assessing vulnerability and community capacity, increasing community capacity to deal with disasters through training and simulation, strengthening community-based communication networks, improving countermeasures disaster, as well as spatial planning oriented to disaster risk reduction. On the one hand, through a continuous 
awareness process, it is expected that in the next few years the conventional group of companies as described above will decrease dramatically, shift into a progressive company or even make the leap to become the leading company. Although changing the mindset is certainly not an easy job, but through ongoing efforts, the change can certainly be done. If a variety of employers' social responsibilities related to disasters are shown consistently, then companies can expect that social permits to operate, namely the support of the surrounding community, stakeholders, and the wider community, will continue to be obtained.

Considering that Karo district is a region that has a high risk of Eruption of Mount Sinabung disaster because it is located in a disaster-prone area. This condition can be "utilized" by the company to carry out the process of fostering stakeholder relations through a variety of strategic initiatives related to disaster management, such as assessing vulnerability and community capacity, increasing community capacity to deal with disasters through training and simulation, strengthening community-based communication networks, improving countermeasures disaster, as well as spatial planning oriented to disaster risk reduction. On the one hand, through a continuous awareness process, it is expected that in the next few years the conventional group of companies as described above will decrease dramatically, shift into a progressive company or even make the leap to become the leading company. Although changing the mindset is certainly not an easy job, but through ongoing efforts, the change can certainly be done. If a variety of employers' social responsibilities related to disasters are shown consistently, then companies can expect that social permits to operate, namely the support of the surrounding community, stakeholders, and the wider community, will continue to be obtained.

"NGOs as supervisors of the Post Disaster Reconstruction and Recovery Program. Along with the end of the post-disaster emergency, many international/local institutions, individuals and volunteer groups left the location to end their humanitarian duties. "(Interview with Director of Walhi North Sumatra Dana Tarigan, August 9th 2016 )

As stated in the previous section, the main focus is on the government and local NPOs / NGOs who act as outsiders in handling the eruption of Mount Sinabung. On the other hand NGOs, or local self-help groups (KSM), individuals, families and local community/community groups as insiders. In this case, after an emergency, the community / local community has been oriented as the subject of development, and not only treated as an object. Likewise, government and NGO creatives in Karo district in tackling the eruption disaster of Mount Sinabung have had to shift to place themselves as regulators, facilitators, motivators, catalysts, educators and dynamists in the post-disaster reconstruction and rehabilitation process.

In terms of the physical environment, in order to realize the sustainability of natural resources, NGOs continue to 
Ian Pasaribu \& Fernanda Putra Adela, Mount Sinabung Eruption Collaboration Model in a

improve, improve and improve urban facilities/infrastructure as well as maintain and optimize the maximum use for community members/communities with insightful management environment. In terms of economic sustainability, it continues to strive for creativity to be able to create and improve the quantity and quality of products/commodities that have a competitive advantage based on the potential and uniqueness of the local context in order to increase the level of income of the community. Likewise in the social, political and cultural fields, they continue to develop the attitudes and behaviours of citizens/communities that are able to create a harmonious life together, both relations between human beings and human relations with their environment in order to realize social sustainability in tackling the eruption of Mount Sinabung disaster.

Associated with efforts to build preparedness in disaster management based on local communities, in addition to continuing to complete the various facilities and infrastructure needed, they also carried out various forms of socialization and even education and training carried out on an ongoing basis. One of the concrete forms of collaboration between the government, NGOs and community members/grassroots communities in building disaster management preparedness.

In fact, the role of the community was involved in the pre-disaster, during the disaster, and in the aftermath of the disaster, especially in the disaster of the Sinabung eruption where the community played a role. Community Participates in making disaster risk analysis, Conducts research related to the disaster, Creates Community Action Plans, Active in Disaster Management Forum in Sinabung, conducts disaster prevention efforts "(interview with USU FISIS professor Hamdani Harahap on 8 August 2016). Society is the most important and central part of disaster management. Because the community is the main victim when a disaster occurs.

\section{Disaster Management Policies Obstacles}

So far, the disaster relief eruption of Mount Sinabung is only limited to post-disaster. Law No. 24 of 2007 concerning Disaster Management has been issued in response to the need for a reliable disaster management system in Indonesia. Since the issuance of this law and continued with the issuance of Government Regulation No. 21 of 2008 concerning the Implementation of Disaster Management, Government Regulation No. 22 of 2008 concerning Aid Funding and Management, Government Regulation No. 23 of 2008 concerning the Participation of International Institutions and NonGovernment Foreign Institutions in Disaster Management and Presidential Regulation No. 8 of 2008 concerning the National Disaster Management Agency,

The hopes of the community in such a great way will soon be the realization of established disaster management in Indonesia so that the new institution is expected to be able to overcome every disaster event in Indonesia. Although 
information and dissemination of information related to the threat of disasters in Indonesia through various media continue to be voiced, our awareness of threats it's still very minimal. (Maarif, 2012: 75)

The understanding of the Mount Sinabung eruption threat paradigm really came true and will be quickly forgotten as time goes by and the loss of media coverage covering Mt. Sinabung. The Mount Sinabung disaster event shows that even though this area has received tremendous attention in preparing its citizens to face eruption hazards, during the actual event there was still a long panic. Some of the causes of this panic include the lack of understanding of the characteristics of the threat so that this threat is not well anticipated during a disaster.

The condition was severely damaged in the Mount Sinabung area which was devastated due to volcanic ash eruption of Mount Sinabung which was not previously calculated, for example, which looked not serious.

UU no. 24/2007 has mandated the need to understand the characteristics of threats, disaster risk and the preparation of anticipatory plans for the eruption of Mount Sinabung in Karo District, however, because this regulation is still relatively new, the socialization of regulations and technical guidelines has not yet reached the Karo district community at large.

An understanding of the Mount Sinabung eruption event can be approached with various fields of science or in other words a multi- disciplinary approach. This is related to the main factors causing the disaster of Mount Sinabung eruption which is a function of hazards and vulnerability.

Hazards or in Indonesian are often interpreted as threats or dangers, which are interpreted as phenomena or natural or human events that can cause damage, loss and/or human casualties. Whereas vulnerability is the inability of humans or communities to face threats due to physical, economic, social, cultural and environmental factors. Because the natural phenomenon of Mount Sinabung eruption is a natural process of the physical and chemical balance of the universe which is often beyond human ability to control the process, efforts to reduce hazards are often ignored and are considered something that will almost certainly happen.

The general response to the eruption of Mount Sinabung eruption is still considered an incidental activity during the emergency response. Comprehensive handling at the top of the leadership already exists, but at the level of its implementation, the handling of an eruption of Mount Sinabung is still constrained due to a lack of understanding and weak capacity of disaster management institutions in North Sumatra and Karo district.

Mount Sinabung eruption supervision, especially the issuance of building permits, must be true based on building technical standards. The application of "building code" is a must for areas threatened by the eruption of Mount Sinabung. 
A vulnerability is a condition of people's inability to face the threat of an eruption of Mount Sinabung. This vulnerability is affected by several factors including physical, social, economic and environmental. A physical vulnerability is the most easily identified vulnerability because it clearly looks like physical disability (disability, illness, old age, road damage and so on), while other vulnerabilities are often rather difficult to clearly identify.

The social vulnerability of the Karo district community which when the disaster is individualistic turns out to be higher than the vulnerability of rural/rural communities that still have high solidarity as social capital. Social capital in the form of high social solidarity if followed by community empowerment programs at least reduces the impact of the disaster, both casualties and property due to the eruption of Mount Sinabung "(Interview with Secretary of Karo Regency BPBD Johnson Tarigan on 2 July 2016)

This is evident in several areas affected by the eruption of Mount Sinabung, always the first responders were the people and they were able to save the victims of the Mount Sinabung eruption from fatalities in the initial period of the incident before outside assistance came. Environmental conditions in Karo Regency are also one of the vulnerability factors of the Karo Regency community. Poor environmental conditions will exacerbate the imnact of disasters that
Settlements that are not well-organized cause access to emergency relief assistance to be disrupted so that early handling cannot be carried out immediately which results in the incident developing into a disaster. For example, house fires in densely populated settlements which spread and spread to burn more than 1 Regional Unit (RW). Community empowerment by raising or operating the potential of existing resources in the community to help reduce the level of community friendliness. The key factor for its success is understanding the characteristics of the threats and risks that exist so that action choices can be established that are in accordance with the threats and resources available in the community of Karo district, North Sumatra.

Image 1. Mount Sinabung Disaster Management Cooperation Scheme 


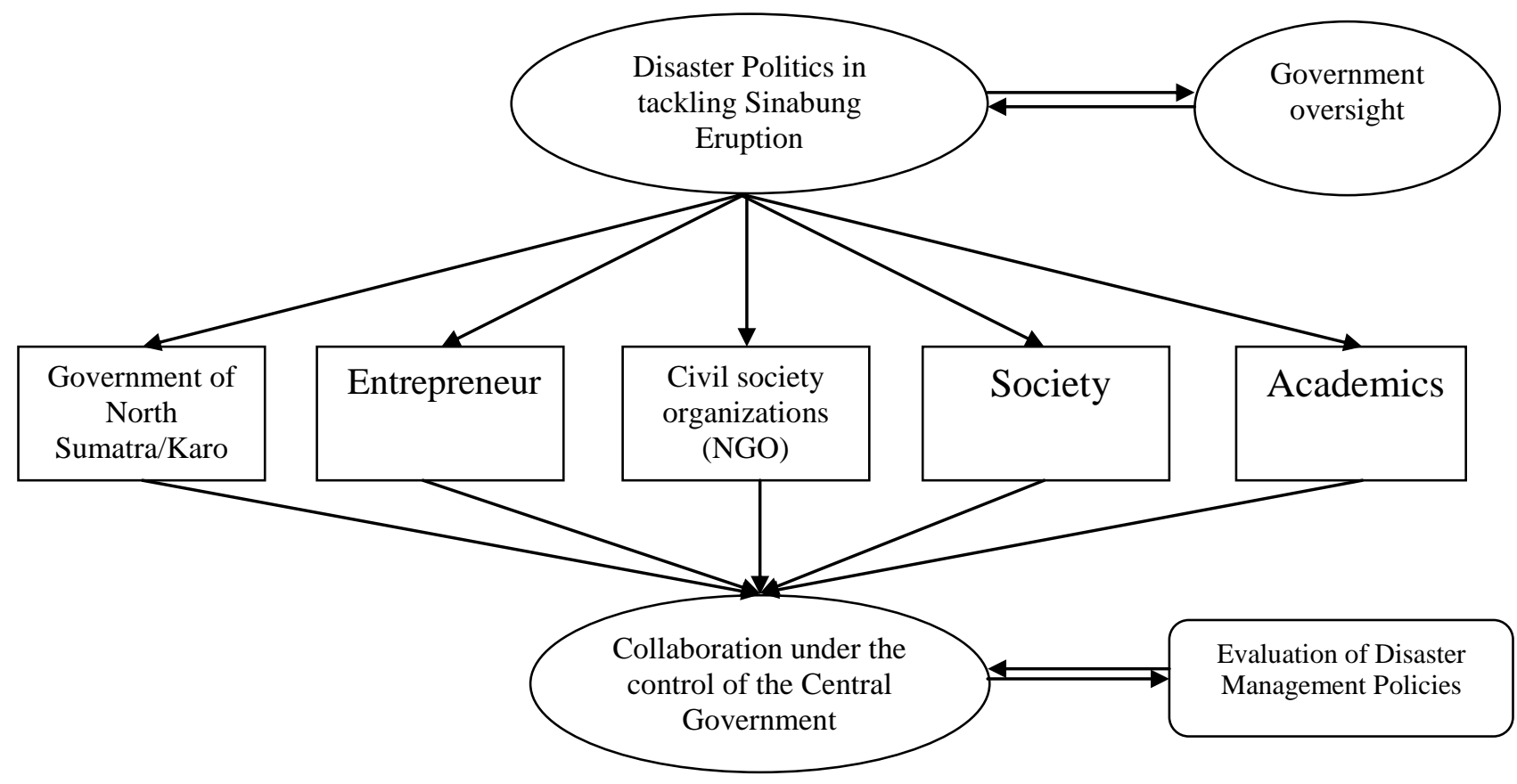

The choice of action was made based on the policies made in the disaster management plan for $\mathrm{Mt}$. Sinabung Eruption. Therefore the action taken for Mount Sinabung Eruption is to avoid risk through the collaboration of government, employers and NGOs. For example, relocating victims of Mount Sinabung Eruption which is threatened by volcanic ash. This action is often less popular, except if the threat is so real or the community is hit by an eruption of Mount Sinabung Eruption in North Sumatra Karo District traumatized by the disaster experienced in the area or nearby which is close to Karo Regency.

Even this trauma is sometimes only temporary, if the trauma has recovered, they will return to receive the risk that is too high to endanger the safety due to Mount Sinabung Eruption. For this reason, increasing awareness and awareness of risk needs to be carried out through various media at every opportunity
Even so, the knowledge that comes from past experiences inherited from our ancestors in the form of local wisdom and noble cultural values, we must continue to consider and preserve. Changes in natural phenomena caused mostly by human activities often exacerbate the impact of disasters due to the eruption of Mount Sinabung.

The dynamics of these changes also increase the complexity of handling the Mount Sinabung Eruption disaster, so that the timing of disasters and their intensity becomes increasingly difficult to predict accurately. This uncertainty is a challenge for disaster management actors to be able to carry out the task of rescuing people living in disasterprone areas through multi-disciplinary and multi-sector approaches and preparing disaster anticipation planning with scenarios in the form of cooperation between interests in Karo Regency, Sumatra North. 
Ian Pasaribu \& Fernanda Putra Adela, Mount Sinabung Eruption Collaboration Model in a

Identification of the risk of Mount Sinabung eruption begins with the introduction of profiles or characteristics of hazards (assessment), then learn at-risk elements in the form of vulnerability assessment. Disasterprone maps as a result of hazards assessment, almost all types of disasters are available in North Sumatra Karo Regency even though it is still on a small scale. In several districts/cities, disaster-prone maps have been prepared on a larger scale.

BNPB continues to push for detailed maps of each hazards to be prepared and determined by the governor of North Sumatra and the Regent of Karo. After the risk of the Mount Sinabung Eruption disaster identified its types and characteristics, the risk must be assessed to predict the likelihood of its occurrence and impact due to the Sinabung volcanic ash.

Calculation of possible damage to buildings/infrastructure may be easier than predicting the possibility of a disaster will occur. For this reason, predictions are needed based on scientific studies that can be accounted for the required risk management plan. The most fundamental difficulty in risk assessment is the unavailability of records of past disaster events data, while disasters, especially natural disasters, are very likely to occur repeatedly in a certain period. This trend will be read well if disaster data is fully recorded over a long period of time.
Currently, North Sumatra and Karo BPBD prioritize data collection on Mt. Sinabung Eruption events and build a disaster database that we call DiBi (Indonesian Disaster Data and Information) in Karo District, North Sumatra. This data is published in the annual book form and displayed on our website. The final results of this risk assessment are risk maps and risk index maps. The BPBD in collaboration with stakeholders in North Sumatra supported by several other stakeholders is currently developing a risk map and risk index with the Karo district analysis unit. Even the index map that mitigates the Mount Sinabung Eruption is only seen as a relief and rescue effort and temporary emergency repairs. It is expected that in all phases of disaster management it must be based on a comprehensive and integrated plan in the development plan.

Every disaster response in Indonesia including Mount Sinabung eruption is inseparable from the interests and political role of the stakeholders involved in this case the government as a regulator of each relate to disaster management. The Karo district government as a policyholder including policies in disaster management should have formulated a quick way to cope with the disaster of Mount Sinabung eruption from pre-disaster, during disasters and post-disaster.

Countermeasures have never been separated from a political perspective, while the intent of 
political perspectives is political tugof-war starting from policymakers, namely the Government with Entrepreneurs and of course the public. In disaster management, each stakeholder must have certain portions and have limited involvement that is controlled or supervised by a selfformed body. The mitigation agency is focused on disaster matters, in this case, the eruption of Mount Sinabung.

The institution that was formed must have good governance that is good at monitoring and controlling starting from its formation to its application in pre-disaster, during disasters and post-disaster. Good governance is very important to strengthen the political perspective in disaster management.

The involvement of stakeholders karo district government, entrepreneurs and the community who are actively involved in making sinabung disaster management by implementing good governance that is good and inseparable from the attraction of political policy.

Sure enough, what is expected from the mitigation of the Mount Sinabung eruption in a political disaster perspective and the good governance is finding the best solution to overcome the problem of sustainable Mount Sinabung eruption with good cooperation and coordination between the relevant stakeholders.

Collaboration and coordination of government stakeholders, entrepreneurs and the community formed in an organized body through the roles of political actors that produce the best solution in overcoming the eruption of Mount Sinabun

\begin{tabular}{|c|c|c|c|}
\hline No. & Research Focus & Finding in Fields & Information \\
\hline 1. & $\begin{array}{l}\text { This research was conducted } \\
\text { in Karo District, North } \\
\text { Sumatra Province. The } \\
\text { researcher examined the } \\
\text { Collaborative Eradication } \\
\text { Eruption Cooperation Model } \\
\text { in the Disaster Political } \\
\text { Perspective. Formulation of } \\
\text { the problem in this study, } \\
\text { Collaboration and } \\
\text { Coordination of stakeholders } \\
\text { in mitigating the eruption of } \\
\text { Mount Sinabung. }\end{array}$ & $\begin{array}{l}\text { At the beginning of this } \\
\text { study, the researchers } \\
\text { believed that the ideal } \\
\text { cooperation } \\
\text { coordination in disaster } \\
\text { management in sinabung } \\
\text { was a coordination } \\
\text { collaboration that was able } \\
\text { to establish good } \\
\text { cooperation and } \\
\text { coordination between all } \\
\text { stakeholders both internally } \\
\text { and externally so that each } \\
\text { organizational unit was able } \\
\text { to carry out its functions } \\
\text { and their respective duties }\end{array}$ & Complete \\
\hline
\end{tabular}




\begin{tabular}{|c|c|c|c|}
\hline & & $\begin{array}{l}\text { in order to achieve the } \\
\text { effectiveness of disaster } \\
\text { management. Very } \\
\text { important coordination in } \\
\text { disaster management in } \\
\text { Sinabung is intense because, } \\
\text { in the implementation of } \\
\text { disaster management, one } \\
\text { organizational unit will not } \\
\text { be able to walk alone } \\
\text { without being associated } \\
\text { with other organizational } \\
\text { units. } \\
\text { But the new discoveries in } \\
\text { this research are: } \\
\text { 1. It turns out that } \\
\text { collaboration between } \\
\text { stakeholders is not maximal } \\
\text { because of unspecified legal } \\
\text { umbrella issues. } \\
\text { 2. Sinabung is not a national } \\
\text { disaster so it is difficult to } \\
\text { determine how to handle it. } \\
\text { 3. Relocation mitigation in } \\
\text { Siosar, Karo district is still } \\
\text { an ordinary stage, in this } \\
\text { effective and efficient. } \\
\text { maxe, it has not been } \\
\text { m. Cooperation in handling } \\
\text { mount Sinabung disaster } \\
\text { that thement will be useful } \\
\text { mazed. }\end{array}$ & \\
\hline 2. & $\begin{array}{l}\text { This research was conducted } \\
\text { in Karo District, North } \\
\text { Sumatra Province. The } \\
\text { researcher investigated the } \\
\text { Mount Sinabung Eruption }\end{array}$ & $\begin{array}{l}\text { At the beginning of this } \\
\text { study, researchers believed } \\
\text { that the main obstacle to } \\
\text { disaster management policy } \\
\text { in North Sumatra was that it }\end{array}$ & $\begin{array}{l}\text { So far it has } \\
\text { been fulfilled } \\
\text { and the data } \\
\text { is adequate. }\end{array}$ \\
\hline
\end{tabular}




\begin{tabular}{|c|c|c|c|}
\hline & $\begin{array}{l}\text { Collaboration Model in a } \\
\text { Disaster Political perspective. } \\
\text { Formulation of the problem } \\
\text { in this study, the disaster } \\
\text { management policy } \\
\text { constraints in North Sumatra } \\
\text { so that it has not succeeded in } \\
\text { resolving the disaster of the } \\
\text { sinabung eruption. }\end{array}$ & 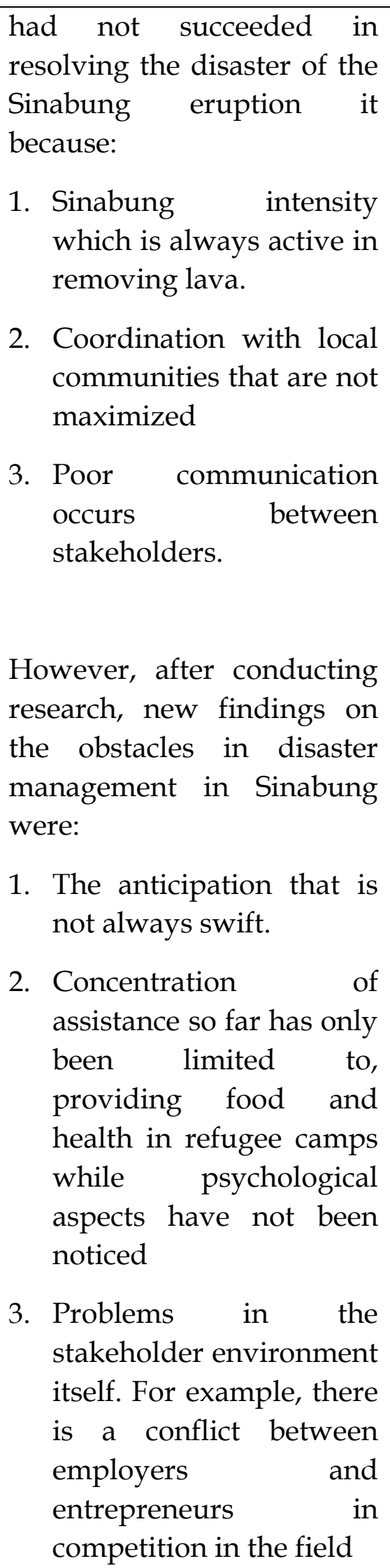 & \\
\hline 3. & $\begin{array}{l}\text { This research was conducted } \\
\text { in Karo District, North }\end{array}$ & $\begin{array}{l}\text { At the beginning of this } \\
\text { study, researchers believed }\end{array}$ & $\begin{array}{l}\text { Model } \\
\text { attached }\end{array}$ \\
\hline
\end{tabular}




\begin{tabular}{|c|c|}
\hline $\begin{array}{l}\text { Sumatra Province. The } \\
\text { researcher investigated the } \\
\text { Mount Sinabung Eruption } \\
\text { Collaboration Model in a } \\
\text { Disaster Political perspective. } \\
\text { The formulation of the } \\
\text { problem in this study is the } \\
\text { Mount Sinabung Eruption } \\
\text { Collaboration Model in a } \\
\text { Political Disaster perspective }\end{array}$ & 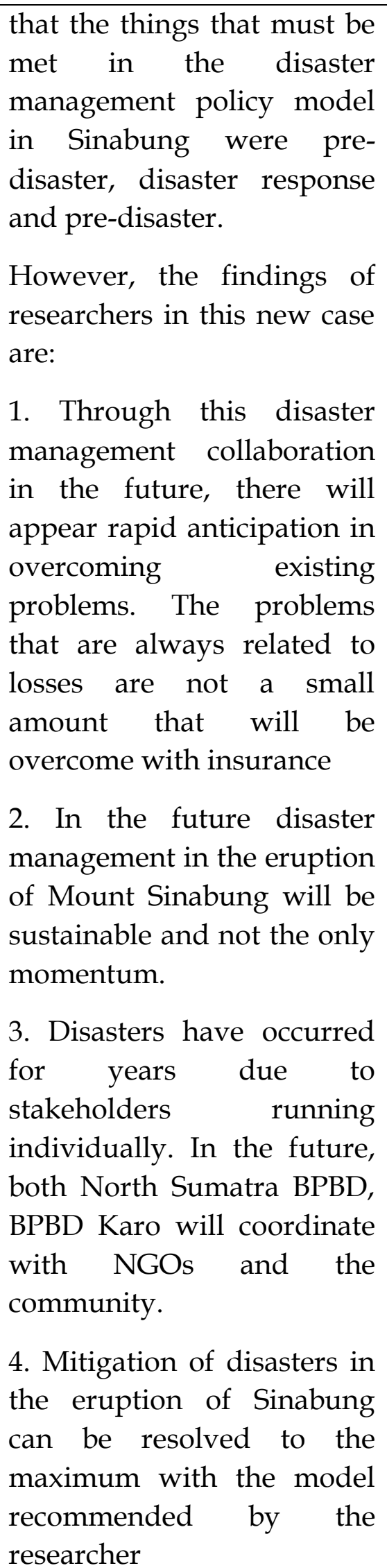 \\
\hline
\end{tabular}




\section{CONCLUSION}

Managing disasters on Mount Sinabung cannot be done only by impromptu or incidental methods but must be carried out in a planned manner with good management, long before a disaster occurs through a process called disaster management. The implementation of disaster management is a series of efforts which include the establishment of development policies that consist of the occurrence of disasters, disaster mediation activities, emergency response, and rehabilitation. Mount Sinabung Eruption handling requires seriousness in handling it.

First, cooperation in handling Mount Sinabung disaster management will be useful for accelerating recovery so that the handling is more effective and efficient.

Second, through this disaster management collaboration in the future, there will appear rapid anticipation in overcoming existing problems. The problems that are always related to losses are not a small amount that will be overcome with insurance.

Third, in the future disaster management in the eruption of Mount Sinabung will be sustainable and not the only momentum.

Fourth, disasters have occurred for years due to stakeholders running on their own. In the future, both North Sumatra BPBD, BPBD Karo will coordinate with NGOs and the community.
Fifth, mitigation of disasters in the eruption of Sinabung can be resolved to the maximum with the model recommended by the researcher.

\section{BIBLIOGRAPHY}

Djojosoekarto, A. \& S, Utama. (2008). Democratic Transformation of Political Parties in Indonesia. Jakarta: Partnership

Wibawanto, A. (2006). Strategy for Winning Elections - Winning People's Hearts and Thoughts. Yogyakarta: Pondok Edukasi. Moertopo, A. (1974). National Political Strategy. Jakarta: CSIS.

Firmanzah. (2007). Political Marketing. Jakarta: Torch.

Nanawi, H. (1992). Research Instrument in the Social Sector. Yogyakarta: Gadjah Mada University Press.

Friedman, L.M. \& Ali, A. (2002). Revealing the Veil of Law. Jakarta: Mount Agung.

Moleong \& Lexy, J. (2007). Qualitative Research Methodology. Bandung: PT Adolescent Rosdakarya Offset.

Miles, M. \& Huberman, M. (1992). Qualitative data analysis. Jakarta: IU Press.

Nazir, M. (1988). Research methods. Ghalia Indonesia.

Deddy, M. (2004). Qualitative Research Methodology. Bandung: PT Remaja Rosdakarya. 
Ian Pasaribu \& Fernanda Putra Adela, Mount Sinabung Eruption Collaboration Model in a

Nasution. (2003). Research Methods: Scientific Research, Jakarta: PT. Earth Literacy.

Gajah Mada University Press.

Sukmadinata. (2005). Educational Research Methods. (Bandung:

Schroder, P. (2004). Political Strategy. Jakarta: Friedrich Naumann Stiftung. Teenager Rosdakarya.

International Idea (translation), Women in Parliament: Not Just Amount

Pujosuwarno, S. (1992). Practical Instructions for Counseling. Yogyakarta: Menara Mas Offset. from (AMMEEPRO; Jakarta, 2002)

http://id.wikipedia.org/wiki/Komisi

Sukandarrumidi. (2002). Research _Pemilihan_Umum Methodology Practical Instructions for Beginner Researchers. Yogyakarta: 